\title{
IMPLEMENTATION OF ECLECTIC METHOD ON ARABIC TEACHING AND LEARNING
}

\author{
Ismail Suardi Wekke*, Shovi Maryam** \\ *Sekolah Tinggi Agama Islam Negeri (STAIN) Sorong \\ **Universitas Negeri Malang \\ Email: iswekke@gmail.com \\ shovimaryam@gmail.com
}

\author{
Presented in \\ International Seminar on Islamic and Arabic Education in Southeast Asia \\ Universitas Muhammadiyah Malang \\ Malang, February 3-4, 2017
}

\begin{abstract}
Mastering both Arabic learning method and material substance should be done simultaneously. The fact shows that teachers are always facing new method and required to evaluate method they have implemented. In the other hand, they are also experiencing difficulties when implementing the method with no strong mastery of materials. Therefore, the two are should be mastered by teachers simultaneously. This paper discusses at least four considerations to implement eclectic method. The method which is considered having excellence in a time may be considered having shortcoming in another time. The implementation of Arabic language, particularly, is supervised and corrected by the sticking coach directly. Correcting and improving students' ability in Arabic language require a long process, not all incorrectness can be corrected directly, since the improvement of language requires times, stages and coach's wisdom to motivate and guide the students. Finally, this paper presented that each of the very great number of methods existing, obviously, has its excellences and shortcomings.
\end{abstract}

Keywords: Arabic, process, implementation, eclectic

\section{INTRODUCTION}

Problems around methodology are not only regarding how to transfer knowledge directly but also how to lead the students to do self-learning and seek information (Abi Aad, 2011; Alkharusi, 2008). Therefore, an appropriate method will provide motivation for the students to continue their learning process. The embedded motivation may lead the students to be able to seek information both by them and by teacher guidance. One way to motivate students who have had Arabic basic ability is by give them chances to transfer or teach it to others (Abdul Razzak, 2016; Al-Eraky, Donkers, Wajid, \& Van Merrienboer, 2015; Alhabahba, Pandian, Mahfoodh, \& Gritter, 2016). Based on this, Arabic learn in Islamic boarding schools proves that students have been trained and have had ability are required to teach other students under the control of lingual supervisors. This is aimed on giving chances and teaching them responsibilities on what they teach now, before and after. 
This kind of model is not found in any Islamic schools except like a kind of peer tutors. In fact, methods of Arabic learn from time to time experience dynamics and development. Methods are designed to achieve the goals, starting from the simpler goal to the most complex or greater one (Alnefaie, 2016; Azmi, 2006; Wekke, 2015). For instance, formerly, translation mode was the dominant method, which now is added by some other methods such as method of mubasyarah and others. Mubasyarah method (direct method) is generally implemented by Islamic boarding school outside of formal lesson hours that is in boarding school activities since Islamic boarding schools have their own curriculum in addition to Islamic school curriculum (Betawi, 2013; Boudelaa \& Marslen-Wilson, 2012; Wekke, 2016).

\section{CONSIDERATION UNDERLYING THE SELECTION OF LEARNING METHOD}

The implementation of eclectic method is based on some considerations. The first is the expected goals. A teacher should be able to fix a method considered the most appropriate on to implement to achieve the goals have been formulated (Elbih, 2015). The second is the Arabic teacher ability. The effectiveness of a method implementation is influenced by teacher's ability. When a teacher has mastered materials he/she are/will teach, it means that he/she has solved a problem. The next problem is how to teach easily or effectively. Usually teachers mastering materials feel more easily to teach when they have knowledge about methodology of Arabic teaching (Fox \& Alldred, 2015). The third is the protégé. Individuals have respective ability, smartness, characteristic, social background which are usually different each other to select an appropriate method (Gregory, Walker, McLaughlin, \& Peets, 2011). The fourth is situation and condition including building, school and classroom physical conditions as well as conditions of teacher and students during the process of Arabic learning (Goldstein, 2016; Wekke, 2017). The fifth is facilities and infrastructures/media of learning which help to ease the presentation of materials and information and make them to be clearer, to enhance and direct students attention, which in turn will raise their motivation to learn (Hill, 2015). In addition, the availability of facilities is being an important aspect in selecting and implementing a method (Domingos-Grilo, Reis-Grilo, Ruiz, \& Mellado, 2012). The sixth is the availability of time. The availability of time is considered enough to implement a method where the goals will be achieved by using the method and during the time available, the method can be implemented (Compton, 2009; Wekke, \& Andriansyah, 2016).

On the other hand, the method is considered neither effective nor efficient, it will be considered not feasible to be implemented and it means that teacher should seek another 
method which is more effective and efficient (Jewitt, Xambo, \& Price, 2016; Litvin, Walkling, \& Cormack, 2016; Loomis, Rodriguez, \& Tillman, 2008). Such method considered more suitable or less suitable according to the learning objectives achievement. All methods are completing each other and even they may be combined in the implementation since no method is perfect except by combining excellence and appropriateness views to enhance the effectiveness of Arabic learning (MacArthur, 1997; McKim, 2004; Michael \& Rajuan, 2009).

As for assumptions in eclectic method as follows: a) each method has its excellence which can be taken for Arabic teaching, b) each method has positive aspects can be compromised harmonically and c) no method is suitable for all goals, learners, teachers and programs. The three aspects are the basic assumption to determine methods which will be combined. Principally, the effectiveness of the method of Arabic learn is determined by many factors including the third assumption above (Murre-Van den Berg, 2016; Natour, Darawsheh, Sartawi, Marie, \& Efthymiou, 2016).

\section{PROCEDURES TO IMPLEMENT ECLECTIC METHOD}

The implementation of eclectic method in Islamic schools and Islamic boarding schools always emphasizes on the following things are: first, Maddah (learning) materials are selected from words and structures of sentences which are widely used in daily life and scientific activities. This emphasis is found in the teaching of Arabic in Islamic boarding schools which are different with Islamic schools since there is slightly limitation in Islamic schools and vocabularies are provided in textbooks. Second, Grammars (قو اعدالنحوو الصرف)are learned orally then they try to make up stories. Third, doing listening (الاستماع), imitating and writing activities frequently that are aimed at achieving lingual mastery automatically (O’Sullivan, 2012; Ross, 2016; Samarji \& Hooley, 2015). Those are more possible to do outside of Islamic boarding school's formal lesson hours. But it is not feasible for Islamic schools which has just 2 lesson hours per week. Fourth, Reading is initially done orally with an awareness of that the learned language is a foreign language. Fifth, language skill is learned starting from al-muhadatsah, al-kitaabah, comprehension till al-qira'ah, sequentially. It also can be adjusted to times, situations and facilities available. Internet and web-blog media facilities are also possible to use to seek learning materials (Reynolds \& Deeken, 2003; Vincent, Neal, \& Iqbal, 2016).

In order to direct the students/learners to achieve communicative competence, the main required thing is vocabularies followed by grammatical skills and language environment. Fundamental difficulties experienced by Arabic learners are lack of vocabularies and lingual 
structures (Zetie, 2002; Zhou \& Fink, 2003; Wekke \& Sahlan, 2014). This occurs in several Islamic schools and Islamic boarding schools. Nevertheless, students of Islamic boarding schools generally have better mastery of vocabs then students of Islamic schools (Lambe, 2011; Mercier-Laurent, 2010; Tach, 2002; Thakur \& Anbanandam, 2015).

Memorizing is not the only way to master structures of sentences but also by practices and making them embedded in students' minds by high-frequency repetition (Ellis, Jarkey, Mahony, Peat, \& Sheely, 2007; D. S. Evans \& Vergnaud, 1998; Lawton \& Barnes, 1998). Implementing models requires sticking supervision (Dinh, Rinfret, Raymond, \& Thi, 2013; L. Evans, 2004). Furthermore, Islamic boarding school system, like Pesantren IMMIM of Makassar, takes 'coach' as sticking coach. The different thing is that Islamic boarding school is still using nazhariyah al-furu' approach which shows that there are many branches of Arabic learn. Some Islamic boarding schools and Islamic schools apply nazhariyah alwihdah approach within formal lesson according to the curriculum for Islamic school presented by The Ministry of Religious Affairs of the Republic of Indonesia.

\section{CONCLUSION}

Since every method has its own excellences, eclectic method is also having excellences are, firstly, combination of excellences of some methods so that they can complete each other or, at least, minimize their shortcomings. Secondly, the eclectic method, in its implementation, contains varied aspects which can motivate and increase students' interest to learn. Thirdly, lingual development and competence of students are in balance. This can be achieved since this method is not focusing on grammatical (قو اعد), tarjamah and mubasyarah (direct) methods, but beyond that, some methods are combined, if necessary. Meanwhile, shortcomings of eclectic method are including, among others, firstly, not all teachers are able to compromise direct method and grammar-translation flexibly and alternately. Secondly, in the application stage, it is impossible to be used completely unless the program is handled by particular institution. Thirdly, there is imbalance of materials and wide complexes with available times. The three items are often problematic, but regarding the second item, it seems that no particular institution is needed, but everyone can apply when the teacher is able and there is supporting environment.

\section{REFERENCE}

Abdul Razzak, N. (2016). Teachers experiences with school improvement projects: The case of Bahraini public schools. Cogent Education, 3(1), 1-18. 
Abi Aad, A. (2011). Visual Transliterations of Oral Combinations of Languages in Lebanon. Iridescent, 1(1), 82-91.

Al-Eraky, M. M., Donkers, J., Wajid, G., \& Van Merrienboer, J. J. G. (2015). Faculty development for learning and teaching of medical professionalism. Medical Teacher, 37 Suppl 1(November), S40-6.

Alhabahba, M. M., Pandian, A., Mahfoodh, O. H. A., \& Gritter, K. (2016). English language education in Jordan: Some recent trends and challenges. Cogent Education, 3(2016), 114.

Alkharusi, H. (2008). Effects of classroom assessment practices on students' achievement goals. Educational Assessment, 13(4), 243-266.

Alnefaie, S. K. (2016). Teachers role in the development of EFL curriculum in Saudi Arabia: The marginalised status. Cogent Education, 3(1), 1-14.

Azmi, H. (2006). Teaching Information Literacy Skills: A case study of the QU-core program in Qatar University. Innovation in Teaching and Learning in Information and Computer Sciences, 5(4), 1-20.

Betawi, I. A. (2013). The effect of the educational system on teacher non-parental and educational perceptions in Jordan: A comparison study between pre-service and inservice teachers. International Journal of Adolescence and Youth, 18(1), 32-44.

Boudelaa, S., \& Marslen-Wilson, W. D. (2012). Morphological structure in the Arabic mental lexicon: Parallels between standard and dialectal Arabic. Language and Cognitive Processes, 28(May 2015), 1-21. https://doi.org/10.1080/01690965.2012.719629

Boudelaa, S., \& Marslen-Wilson, W. D. (2015). Structure, form, and meaning in the mental lexicon: evidence from Arabic. Language, Cognition and Neuroscience, 3798(April), 138.

Compton, L. K. L. (2009). Preparing language teachers to teach language online: a look at skills, roles, and responsibilities. Computer Assisted Language Learning, 22(1), 73-99.

Dinh, T. Le, Rinfret, L., Raymond, L., \& Thi, B.-T. D. (2013). Towards the reconciliation of knowledge management and e-collaboration systems. Interactive Technology and Smart Education, 10, 95-115.

Domingos-Grilo, P., Reis-Grilo, C., Ruiz, C., \& Mellado, V. (2012). An action-research programme with secondary education teachers on teaching and learning photosynthesis. Journal of Biological Education, 46(2), 72-80.

Elbih, R. (2015). Teaching about Islam and Muslims While Countering Cultural Misrepresentations. Social Studies, 106(3), 112-116.

Ellis, R. a., Jarkey, N., Mahony, M. J., Peat, M., \& Sheely, S. (2007). Managing quality improvement of eLearning in a large, campus-based university. Quality Assurance in Education, 15(1), 9-23.

Evans, D. S., \& Vergnaud, S. (1998). Pedagogical engineering in intercultural teams: critical success factors. International Journal of Educational Management, 12(4), 149-153.

Evans, L. (2004). Language, translation and the problem of international accounting communication. Accounting, Auditing \& Accountability Journal, 17(March), 210-248.

Fox, N. J., \& Alldred, P. (2015). New materialist social inquiry: designs, methods and the research-assemblage. International Journal of Social Research Methodology, 18(4), $399-414$.

Goldstein, O. (2016). A project-based learning approach to teaching physics for pre-service elementary school teacher education students. Cogent Education, 3(1), 1200833.

Gregory, A., Walker, I., McLaughlin, K., \& Peets, A. D. (2011). Both preparing to teach and teaching positively impact learning outcomes for peer teachers. Medical Teacher, 33(8), 417-22.

Hill, P. (2015). The first Arabic translations of Enlightenment literature: The Damietta circle 
of the 1800s and 1810s. Intellectual History Review, 25(2), 209-233.

Jewitt, C., Xambo, A., \& Price, S. (2016). Exploring methodological innovation in the social sciences: the body in digital environments and the arts. International Journal of Social Research Methodology, 5579(February), 1-16.

Lambe, P. (2011). The unacknowledged parentage of knowledge management. Journal of Knowledge Management, 15(2), 175-197.

Lawton, S., \& Barnes, R. (1998). Developing distance learning courses in a "traditional" university. Quality Assurance in Education, 6(2), 106-111.

Litvin, M., Walkling, S., \& Cormack, R. (2016). Full of noises: when "World Shakespeare" met the "Arab Spring." Shakespeare, 12(3), 300-315.

Loomis, S., Rodriguez, J., \& Tillman, R. (2008). Developing into similarity: global teacher education in the twenty first century. European Journal of Teacher Education, 31(3), $233-245$.

MacArthur, J. (1997). Stakeholder analysis in project planning: origins, applications and refinements of the method. Project Appraisal, 12(4), 251-265.

McKim, D. K. (2004). Confessing and Commending the Faith: Historic Witness and Apologetic Method. Theological Studies, 65(1), 202-203. Retrieved from ATLA Religion Database with ATLASerials, EBSCOhost

Mercier-Laurent, E. (2010). Knowledge management: French cooking. Vine, 40(3/4), 301311.

Michael, O., \& Rajuan, M. (2009). Perceptions of "the Other" in Children's Drawings: An Intercultural Project among Bedouin and Jewish Children. Journal of Peace Education, 6(1), 69-86.

Murre-Van den Berg, H. (2016). The language of the nation: The rise of arabic among jews and christians (1900-1950). British Journal of Middle Eastern Studies, 43(2), 176-190.

Natour, Y. S., Darawsheh, W., Sartawi, A. M., Marie, B. A., \& Efthymiou, E. (2016). Reading error patterns prevailing in Arab Emirati first graders. Cogent Education, 3(1), $1-17$.

O'Sullivan, C. (2012). Introduction: Rethinking methods in translation history. Translation Studies, 5(2), 131-138.

Reynolds, R. R., \& Deeken, J. (2003). Cataloging: The good, the bad, and the ugly. Cataloging, The Serials Librarian: From the Printed Page to the Digital Age, 44(1-2), $143-153$.

Ross, J. (2016). Speculative method in digital education research. Learning, Media and Technology, 9884(April), 1-16.

Samarji, A., \& Hooley, N. (2015). Inquiry into the teaching and learning practice: An ontological-epistemological discourse. Cogent Education, 2(1), 1120-1261.

Tach, E. C. (2002). Leadership \& Organization Development Journal. Leadership \& Organization Development Journal, 23, 205-214.

Thakur, V., \& Anbanandam, R. (2015). Supplier selection using grey theory: a case study from Indian banking industry. Journal of Enterprise Information Management, 28(6), 769-787.

Vincent, C., Neal, S., \& Iqbal, H. (2016). Children's friendships in diverse primary schools: teachers and the processes of policy enactment. Journal of Education Policy, 939(January), 1-13.

Wekke, I. S. (2015). Arabic Teaching and Learning: A Model from Indonesian Muslim Minority. Procedia-Social and Behavioral Sciences, 191, 286-290.

Wekke, I. S. (2016). Arabian society in Kaili lands, central Sulawesi: Arabic education and its movement. Tawarikh, 7(1).

Wekke, I. S. (2017). Arabic Language Teaching and Learning in Muslim Minority of West 
Papua. Jurnal Pendidikan Islam, 6(1), 147-168.

Wekke, I. S., \& Andriansyah, A. (2016). From Gontor to Sorong: Muslim Minority Practices on Arabic Teaching and Learning. SOSIOHUMANIKA, 9(1).

Wekke, I. S., \& Sahlan, A. (2014). Strategy in Creating School Environment: Lessons from High Schools in Indonesia. Procedia-Social and Behavioral Sciences, 143, 112-116.

Zetie, S. (2002). The quality circle approach to knowledge management. Managerial Auditing Journal, 17(6), 317-321.

Zhou, A. Z., \& Fink, D. (2003). The intellectual capital web. Journal of Intellectual Capital, $4(1), 34-48$. 